\title{
COMMON CHARACTERISTICS IN THE ORGANIZATION OF TOURIST SPACE WITHIN MOUNTAINOUS REGIONS: ALTAI-SAYAN REGION (RUSSIA)
}

\author{
Aleksandr N. DUNETS \\ Altai State University, Department of Economic Geography and Cartography, \\ Pr. Lenina 61a, 656049 Barnaul, Russia, e-mail: dunets@mail.ru \\ Inna G. ZHOGOVA* \\ Altai State University, Department of Foreign Languages, \\ Pr. Lenina 61a,656049 Barnaul, Russia, e-mail: zhogova.75@mail.ru \\ Irina. N. SYCHEVA \\ Polzunov Altai State Technical University, Institute of Economics and Management \\ Pr. Lenina 46, 656038 Barnaul, Russia, e-mail: madam.si4eva2010@yandex.ru
}

Citation: Dunets A.N., Zhogova I.G., \& Sycheva I.N. (2019). COMMON CHARACTERISTICS IN THE ORGANIZATION OF TOURIST SPACE WITHIN MOUNTAINOUS REGIONS: ALTAISAYAN REGION (RUSSIA). GeoJournal of Tourism and Geosites, 24(1), 161-174. https://doi.org/10.30892/gtg.24113-350

\begin{abstract}
Tourism in mountainous regions is a rapidly developing industry in many countries. The aims of this paper are to examine global tourism patterns in various mountainous regions and to define the factors that differentiate tourism development in the mountainous environments from tourism development in the lowlands. The authors have taken a regional approach to examining these patterns. They consider the mountainous areas to be a system and recommend analyzing them accordingly. The features of mountainous tourist systems and their associated hierarchies are defined in the study. The study involved creating a diagram to depict the differentiation in the tourist space and to identify the types of tourism represented in mountainous areas throughout the world. Reviewing and analyzing studies focusing on tourism in the mountainous areas has allowed the authors to distinguish common features of mountainous regions that influence the organization of tourism space. The authors suggest creating hierarchies to represent the mountainous tourist regions and the transboundary mountainous tourist system. The Altai-Sayan region is featured as one example of a mountainous area that has its own distinguishing characteristics and that faces unique challenges in the development of its tourism industry. The authors suggest that it is possible to identify trans-boundary mountainous tourist systems and tourist regions, specifically in the Altai-Sayan region. The study identifies the main tourist centers and types of transport infrastructure that determine tourist space in this region.
\end{abstract}

Key words: Russia, Altay-Sayan region, mountainous region, regional approach, tourist system, types of tourist regions, tourist space.

* Corresponding author 


\section{INTRODUCTION}

The development of the tourism industry is determined by the diversity of regions throughout the world. Moreover, mountain experience can improve mental well-being and it may be beneficial for people trying to cope with experiences such as stress-inducing disabilities, traumatic experiences and various diseases. There are key factors that determine the organization of a commercial tourism industry in the mountainous areas. In fact, the mountains are often geographically isolated regions where climatic conditions, water resources, flora and fauna and ethnic groups can differ considerably. On the one hand, mountainous areas are very attractive for travelers but their ecological and sociocultural environments can experience huge pressure from negative impacts of tourism in mountain environments. The type of surface is particularly essential for differentiating tourist space in mountainous areas. Its considerable elevation above the sea level and the strong dissection of the relief determine a variety of properties and objects of the natural environment. Mountainous regions are rich in various natural, cultural and historical resources. The mountains of the world are objects of economic development, scientific study and tourist activity. The mountainous areas occupy 24\% of the Earth's land, and about $12 \%$ of the global population lives in the mountainous regions (Jack et al., 1999). In addition, people living in the mountains vary significantly in terms of their living standards and incomes. Also, the mountains are sources of water, energy, agriculture and forestry as well as being main centers of religious, biological and cultural diversity for many people (Godde et al., 200o). It is also of interest to examine differences in the organization of commercial tourism industry in mountainous areas. It is essential to understand where it is difficult to construct and develop a tourism industry. In the present study the Altai-Sayan Region is considered as a model territory in order to compare mountainous areas. It is a trans-boundary region, and it is located in the center of Eurasia. The Altai-Sayan Region is famous for highly diverse landscapes, tourist attractions and remoteness from the main economic centers, and low standards of living.

\section{Literature review}

Mountainous areas are a unique system of landscapes. The physical-geographical mountainous region is a part of the continent that is characterized by the geomorphological unity of the territory, the similar macroclimatic conditions, types of landscape diversity and high - altitude zone of landscapes (Godde et al., 2000). Mountain regions are vast areas of the land surface with extreme fluctuations of altitudes. Mountain regions are significantly elevated above the plains and they have natural boundaries (tectonic faults, rivers, sharp boundaries of plains). These mountainous regions may stretch for several thousand kilometers and possess very complex configurations.

Many mountainous regions cross state borders. Some scholars consider borders to be dividing lines that represent the end of something and include peripheral characteristics. There are four significant functions of borders: division, connection, conflict and filtering that can be present in concentrated, sporadic, linear and zonal forms. In addition, borders can separate ethnic groups and can even be barriers among ethnic communities. If the border is demarcated after a given ethnic group is settled down and these coincide, boundaries are established. If a border is established after the settlement and the ethnic group has adjusted to the line, the border is called an antecedent boundary. When the border line does not conform to the ethnic group's line of settlement, it is known as a superimposed boundary (Bujdoso et al., 2015).

Scholars in the field of mountainous regions have studied the issues in a proper way. Yu. Seliverstov focuses on the necessity of the interdisciplinary study of the physical, chemical, geological, and biological aspects of mountain regions; the study of the lifestyles 
and economic concerns of people living in these regions - "montology". He states that "montology" should include the achievements of socio-economic sciences, to deal effectively with challenges concerning environmental protection and the dynamic development of the economy and culture in mountain areas in the processes of globalization (Seliverstov, 2002). The montological approach is presented and illustrated in the following literature: Mountains of the World. Global Priority (Jack et al., 1999), Tourism and Development in Mountain Regions (Godde et al., 2000), Mountains and People: Changes in Landscapes and Ethnoses of the Inland Mountains of Russia (Chistyakov et al., 2010). The significance of the integrated study of mountainous regions results in organizing a number of conferences and publications regarding mountainous areas. D.V. Sevastyanov considers "montology" in the frame of integrated regional studies of mountainous areas. In addition, much attention is paid to the issues of sustainable development of mountainous regions in the Institute of Geography of the Russian Academy of Sciences (Badenkov et. al., 1998).

B. Rodoman (2002) highlights the specific nature, the population and the economy in the mountains. The increase of the tourist flow in mountainous regions requires special approaches to the territorial organization of tourist activities, the creation of tourist infrastructure and the functional zoning of the territory. Some scholars state that tourist activities in the mountains should be considered and viewed in terms of tourist environmental management (Suprunenko, 2003). The key difference of mountain lands is a diverse array of habitats in which a large range of plants and animals can be found. Moreover, there are changes in the total solar radiation, air temperature and humidity and oxygen level in the air in mountainous regions. In fact, an increase of absolute altitude can rapidly cause changes of the characteristics of a species' habitat at short distances and has an impact on life-support processes. In the mountains, there is an elevation interval of the ecological optimum for human life and activity (Kalesnik, 1970; Sevastyanov, 2008). Mountainous areas are the largest ecosystems of our planet, which play an important role in the cycling of the planet's substances and energy. Such regions may be of interest for integrated regional studies. They are the most important sources of water, energy and biological diversity, possessing significant mineral, agricultural and tourist resources (Jack et al., 1999; Golubchikov, 1996; Dunets, 2011). Orographic conditions of mountains have an influence on the climate and other components of the environment. Also, the impact extends beyond their borders even in lowlands. Mountain areas are relatively less developed due to the inaccessibility and technical complexity. Economically, mountain populations may also lack of the appropriate skills and the resources to benefit from a tourist industry (Price et al., 2004). Mountain ridges (particularly very high ones compared to other mountains) are often borders between states and administrative entities. The mountains are essential in the territorial structure of the tourist market. Various "high-altitude floors" of mountain areas are characterized by certain types of accommodation facilities (Suprunenko, 2003). Horizontal roughness of relief determines variety and passes ability of the territory. It also determines whether it is possible for vacationers and stuff transportation to travel through the territory and influences the creation of infrastructure associated with recreation (Zhensikbaeva et al., 2017). It should be noted that the AltaiSayan region is mostly examined in the work of Russian scientists,' however, parts of this region have been studied by many well-known scientists (A. Humboldt). For a long time the Altai-Sayan region was viewed as the political borders of Russia and considered in the terms of the different types of environmental management (Rudsky, 2000). V. Revyakin highlighted the features of anthropogenic changes in landscapes of the mountains (Revyakin et al., 2001). M. Sukhova (2009) studied the ecological and climatic potential 
of landscapes for the life of mountain people and recreational nature management. In 2000, with the support of the World Wildlife Fund (WWF), a landscape map of the AltaiSayan region was developed. G.S. Samoilova, an author of the map, notes that steppes landscapes (26\% of the area of the region) and dry steppes prevail among other types of landscapes in this region. For example, taiga occupies $19 \%$, while tundra, alpine/subalpine meadows, glacialnival landscapes make up about $14 \%$ and desert and semi desert landscapes make up approximately $19 \%$ of the region. Interestingly, Altai is characterized by a contrast in landscape diversity (Samoylova, 2000) and states the features of tourism development, its main features and types of tourism in the region (Dunets, 2009).

\section{MATERIALS AND METHODS}

Regional studies and tourism are essential for the integrated study of the tourist space in the region. The methodology of tourist regional studies can be found in the works of M. Ananiev (1975), Yu. Dmitrevsky (1997, 1999, 2000), A. Alexandrova (1996, 2002, 2009). The founders of the Russian school of regional studies are V.P. SemenovTian-Shansky, L.S. Berg, N. Baransky (Sevastyanov, 2008). The scholars of the Institute of Geography of the Russian Academy of Sciences, the Moscow State University, and the St. Petersburg State University contributed much to the development of the theory of regional studies. The methodology of regional studies is interdisciplinary, and it is based on a combination of a number of approaches (analytical, chronological, formal logic, economic, culturological, etc.). Tourist regional studies is the branch of "regional studies" and it studies the patterns of the formation and functions of integral territorial entities (local communities) - various tourist regions. Also, it defines various factors in regional differentiation of tourist space. Much of the work on "geography of tourism" is concerning tourist regional studies. Its research subject is the tourist space of the region from units of higher taxonomic levels (for example, North-Western Europe, Southeast Asia), the level of the country, tourist regions in the state.

The continual and discrete elements in the structure of the tourist space make it possible to study the space in terms of the geosystemic approach. The key concept in the study of the tourist space of the regions is "organization", which includes the structure, functions and interrelationships of structural elements. More specifically, the organization of the tourist space of the mountain region is easily understandable. The mountain region can be a territorial tourist system with its elements, physical and biological features and interrelations. Some researchers state that mountain regions are geosystems in which tourism is the basis of various links such as cultural, economic, ecological, political, social and technological. In such regions, geosystems are formed and containing both the natural and social components (Godde et al., 2000). The tourist system is an essential part of the geosystem of the mountain region. The complexity of tourism development in the mountains is determined by the harsh conditions regarding the development of other systems. The concept of tourism in mountain regions is based on the concept of a discrete and continual tourist space. Among the characteristics of mountain tourist systems, we note:

- vast open spaces;

- low density of tourism infrastructure in the spaces in connection with their concentration in separate places;

- relief influence on the location of the tourist infrastructure;

- services and seasonal demand;

- differences in tourism specialization, depending on the height of the terrain;

- the opportunity to develop different types of tourism in the transitional seasons of the year (rafting and mountain skiing); 
- lack of social and cultural infrastructure;

- insufficient number of staff.

Global, national, regional and local tourist systems are defined in the hierarchy of tourist systems (Mazhar, 2008). In addition, the trans-boundary location of the mountain area determines the perspectives for the formation of mountain tourist systems of a transboundary level of the mountain region (Figure 1). The similarity of the natural and socioeconomic characteristics of the trans-boundary territories and the development of mutually beneficial international cooperation can result in the formation of mountain tourist systems. However, in general, discreteness of mountain tourist systems does not allow the identification of the state and perspectives of tourist space development in the mountain region. Therefore, it is important to study the space where the tourist system develops and interrelates with other regions and systems. As a result, in order to study tourism more effectively, it is necessary to explore the mountain tourist region as a continuum entity.

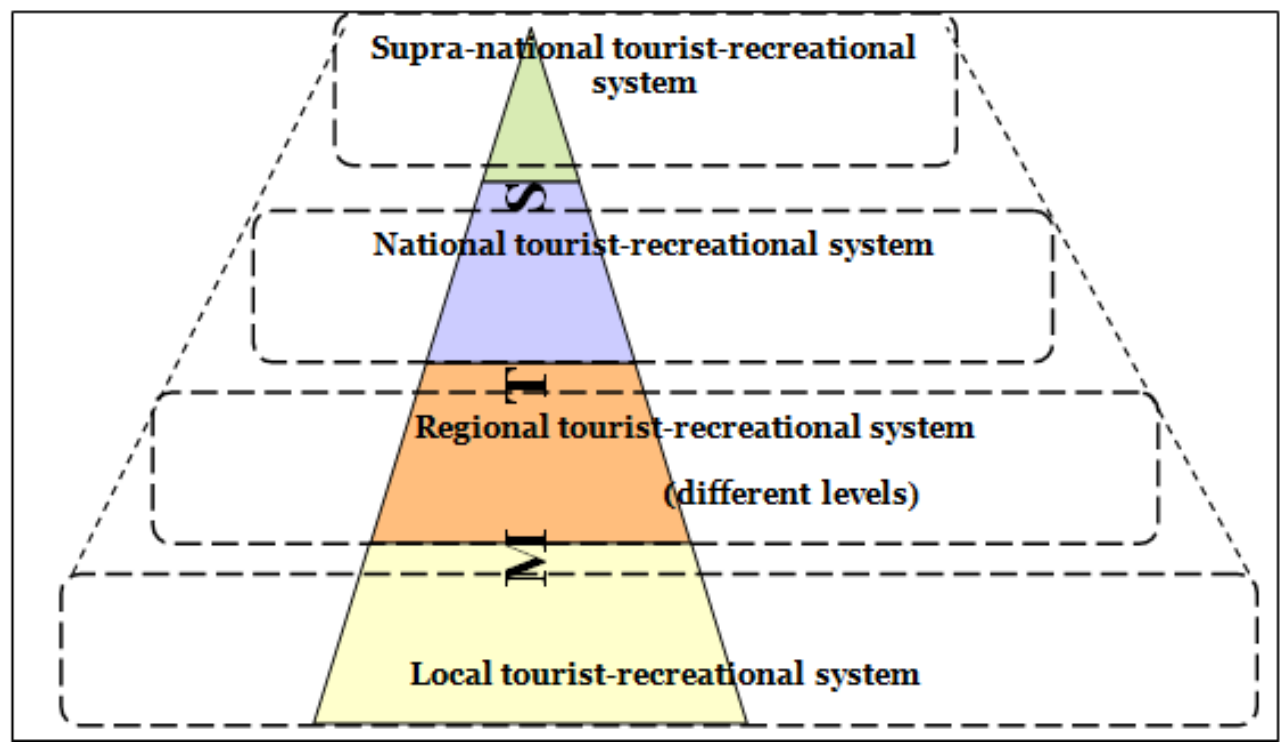

Figure 1. Trans-boundary mountainous tourist system

(MTS) in the hierarchy of territorial tourist systems

Table 1. Hierarchy of mountainous tourist region

\begin{tabular}{|l|l|l|}
\hline $\begin{array}{l}\text { Hierarchical } \\
\text { Level }\end{array}$ & $\begin{array}{l}\text { Territorial Features of } \\
\text { Mountainous Regions }\end{array}$ & Examples of Mountainous Region \\
\hline $\begin{array}{l}\text { Supranational } \\
\text { Macroregion }\end{array}$ & $\begin{array}{l}\text { The region within the natural and historical } \\
\text { boundaries of a mountainous country or } \\
\text { countries located in a mountainous area }\end{array}$ & $\begin{array}{l}\text { the Alpine Region } \\
\text { the Altai-Sayan Region }\end{array}$ \\
\hline Macroregion & $\begin{array}{l}\text { The mountainous region within the } \\
\text { borders of the state }\end{array}$ & the Altai-Sayan Region in Russia \\
\hline Megaregion & $\begin{array}{l}\text { The mountainous region within a big tourist- } \\
\text { recreational region (region) }\end{array}$ & $\begin{array}{l}\text { Tourist Regions: Altai-Kuzbass, } \\
\text { the North Caucasus }\end{array}$ \\
\hline Mesoregion & $\begin{array}{l}\text { The mountainous region within the } \\
\text { administrative entity }\end{array}$ & $\begin{array}{l}\text { the Republic of Altai, the Tyva } \\
\text { Republic and others }\end{array}$ \\
\hline Microregion & $\begin{array}{l}\text { The mountainous region within the tourist- } \\
\text { recreational area or administrative entity }\end{array}$ & $\begin{array}{l}\text { Priteletskiy Region (Lake Teletskoye), } \\
\text { the tourist area "Lake Aya" }\end{array}$ \\
\hline
\end{tabular}


In accordance with the provisions of recreational geography, the tourist system forms the basis of the tourist region. The hierarchy of territorial tourist systems and the existence of its trans-boundary type provide an opportunity for distinguishing different levels of mountain tourist regions, located within territorial entities that have natural, administrative or tourist borders (Table 1). Mountain territorial tourist systems of a transboundary level are of very different sizes. Regions of different hierarchical levels form separate territories possessing terrestrial, administrative-political, ethno-cultural borders. Intersection of natural structures of mountain territories (ranges, rivers) is a foundation for zoning mountain tourist-recreational regions. Information on the hierarchy of mountainous tourist regions and territorial tourist systems are a basis for studying of the process of formation of tourist space in the mountains.

\section{RESEARCH AND OUTCOMES}

It should be noted that European scholars turned to the mountainous regions in the late $19^{\text {th }}$ century, for example, the Alpine mountains were formed into a recreational and entertainment area for tourists from a quiet rural area. The development of transport networks led to tourism development in the region (Beatty, 2008). In the early $20^{\text {th }}$ century people were able to use mountain areas and create economic and social tourist spaces in the mountain areas. In addition, there were necessary prerequisites for the sustainable tourism development. The main tourist areas were coastal and mountainous ones. In the frame of an integrated approach towards a sustainable local development, the tourism industry interacts with ecosystems. Consequently, the development of the tourism industry can be shaped by environmental heritage (Forleo et al., 2017). Essentially, mountainous areas have a marked and complex topography and seasonality, and the factors reduce the construction of resort complexes and prevent increases in international tourist flow (Neidze, 2007; Godde et al., 2000; Price, 2007). However, picturesque mountain landscapes, the impact of human activities on the mountain climate, and opportunities for developing sports facilities have resulted in the sustainable development of the tourist industry over recent decades in the mountains. The ski resort construction is a key factor for building tourist development in the region.

In mountainous regions the proportion of local and foreign tourists differs. For instance, about $40 \%$ of European tourists prefer mountainous areas. In France, domestic tourists make up 30\% in the mountainous regions. In India, 95\% of tourists visiting the Himalayas (Himachal Pradesh and Uttar Pradesh) are Indians. In Austria, up to $77 \%$ of tourists are foreign tourists. Russian tourists exceed the number of foreigners in the mountainous regions of Russia (Jack et al., 1999). The basis for the tourism development in the mountainous area is the unique combination of natural resources: orography, climate, water, mineral and raw materials, flora and fauna. However, a good part of the resources of mountainous regions has not been used yet. Moreover, the tourist infrastructure is being intensively improved in all regions all over the world. Assessing the mountain resources is an essential requirement of tourist activities, in particular mountain resources, their territorial differentiation and prospects for tourism development. In the case of tourist and recreational development of mountainous areas, the following criteria and properties are assessed: hypsometric, climatic, landscapeaesthetic, glaciological (glaciers, mudflows, avalanches), geodynamic (seismicity, landslides), and also socio-economic (transport networks, infrastructure, good service sectors, labor resources and landmarks) (Vedenin, 1990). Also, the mentioned features determine the type of tourism resources that prevail in the region: rock climbing, mountaineering, health tourism, eco-tourism. The type of recreational use of mountain 
Common Characteristics in the Organization of Tourist

Space Within Mountainous Regions: Altai-Sayan Region (Russia)

resources refers to certain forms of territorial organization : for rock climbing type - a camp, temporary base camps, for mountain tourism - hotels, camps, for health tourism resorts and wellness centers (Suprunenko, 2003). Pilgrimage to the mountainous areas is the oldest form of tourism because mountains are sacred places for many spiritual practices and religions. For instance, in India, a number of pilgrims go to the Indian mountainous states - Himachal Pradesh and Uttar Pradesh. In Japan, more than 1 million people visit Mount Fuji every year. In Altai, pilgrims from different regions of Russia go to Belukha (mountain), they want to find the famous place "Belovodie" and the energy of the place (Neidze, 2007; Godde et al., 2000). In addition to tourist attractiveness in the mountainous region, the accessibility is a very important factor for the tourism development. Over recent decades, Western Europe and the United States have significantly improved transport infrastructure and the quality of mountainous roads. All types of transport can be available in the mountains. Western and Central Europe, in particular, have a widely used railway network. High-speed trains are the fastest way to reach the high mountains in Western Europe, Japan and North America. In these regions, the main roads are gradually merged with a network of cable cars and chairlifts, local roads, and walking/bike trails. In the mountains, airports and helipads have been established. Moreover, gradually transport networks are being developed in Asia, Africa and South America. The construction of highways and railways is crucial for the tourism development along with airlines and air communication being very important for mountainous communities (Jack, 1999). According to the World Tourism Organization, the tourism potential of mountainous regions is based on natural, cultural, and socioeconomic elements that influence tourist flows (Vijulie et al., 2018).

As M. Price notes, tourist mountainous regions currently compete with each other internationally (Price, 1999). It is evident that maximizing economic benefits of mountain regions depends on strategic advantages such as location, location of large settlements, and accessibility. Comparing the organization of tourist space within the natural boundaries of mountainous regions is challenging. One reason for this is the lack of objective statistical data. Information related to tourism in mountainous regions is scant and data is not readily available. For example, information about the amount of internal tourist flow related to adventure tourism and information about accommodation in guest houses is generally not included in statistical reports. Studies on the geography of tourism in countries all over the world have contributed to a foundational understanding of mountain tourism. The classification of countries suggested by A. Aleksandrova, has advanced the understanding of centro-peripheral structure of the international tourist space (Alexandrova, 2009). This classification approach considers countries according to their involvement in the international tourism division of labor (Alekseeva \& Mironenko, 2004). More specifically, modern tourism development involves new regions. Additionally, transportation systems, new information technologies, and the tendency to "blur" the borders have resulted in increasing numbers of tourist centers and the redistribution of tourist flows between traditional and new tourist destinations (Alexandrova, 2002).

The process of globalization plays a crucial role in the tourist industry and has contributed to a spatial hierarchical structure of international tourism. The centers of world tourism development in mountainous regions are formed in economically developed countries of North America, Europe and certain regions of Asia. The periphery consists of the countries of Central and South America, Africa and some Asian countries (Alekseeva \& Mironenko, 2004). Using the isoline approach, W. Ritter and S. V. Odeser defined six types of tourist use of the territory, taking into consideration the level of 
tourist infrastructure development. We used their approach to compare the types of organization of the tourist space and identified the following types based on the analysis of the tourism development of mountainous areas (Resources and environment, 1998):

1. Mountainous areas of the economically developed countries with well-developed infrastructure, functional zoning and significant tourist flows (the Alps, the Appalachian Mountains, the Cordillera and Rocky Mountains, the mountains of Japan);

2. Regions with a high degree of natural resource use and good material-technical base of tourism (the Pyrenees, the Apennines, the Rhodopes, the Carpathians, the Sudetes, the west of the Dinaric Mountains, the Western Taurus, the Appalachians, the south of the Scandinavian mountains, the eastern part of the Great Dividing Range etc,);

3. Regions of developed (wealthy) countries, less densely populated and characterized by medium and low levels of natural resource use and the availability of an extensive-technical base (the Rocky Mountains in Canada, the eastern part of the Balkan Mountains, the Drakensberg Mountains, the north of the Scandinavian Mountains, the southern part of the Andes, the Cape Mountains, north-west of Altai, etc.);

4. Regions characterized by a combination of high levels of natural resource use with low and medium levels of infrastructure provision (accommodation / hospitality facilities) (the Caucasus, the Urals, the Himalayas, western Balkan Mountains, the Atlas, the Andes in the southern part, the Tien Shan);

5. Regions with low levels of natural resource use and poor infrastructure development and countries with low population density that can only take advantage of tourism services to a limited extent (the Altai Sayan, Pamir, the Drakensberg Mountains, the Andes, the Cordillera in Mexico, many mountain ranges of Africa, South-East Asia, etc.);

6. Regions with a scarcity of natural resources to support tourism and that have poor infrastructure (Tibet, a large part of the mountains of the central and northern parts of Siberia, the Tanentundzhi Range, etc.);

7. Regions where tourism is poorly developed due to armed conflicts or civil disorder (the Hindu Kush, part of the Pamirs, the Ethiopian Highlands).

Essentially, mountain ridges can serve as borders between states. In these cases, different ethnic groups living in these regions can be separated by natural (physical) and administrative borders. In addition, ethnic groups can be divided by a state border. Some scholars have asserted that the boundaries can become a "barrier" to cooperation (Badenkov, 2002). Other locations demonstrate how a single tourist space in a transboundary mountainous region can contribute to interaction of diverse ethnic groups (for example, in the Alps). State borders in mountainous regions are represented by physicalgeographical (sea and continental boundaries) with the continental boundaries divided into orographic watersheds and in-basin areas. In addition, state borders in the mountains divide regions into different religious systems: Catholicism, Orthodoxy, Islam, Buddhism. The typology of tourist spaces of mountainous regions can be based on their location, which is determined by physical-geographical and socio-economic criteria (Figure 2). The geographical location can be defined by a position of an area in the parts of the world (European, African, Asian, North American, etc.) by zonal location (equatorial, circumpolar, etc.), and by natural and geographical boundaries.

Also, the geographical location (center, semi-periphery, periphery) is quite essential for economic development of the region. Thus, the combination of several conditions forming a geographic location of a mountainous region can include both negative and positive points in the organization of tourist space. Factors such as: cold (or moderate) belt; cross-border territory; the intra-continental position, ethno-cultural and religious diversity, the periphery of the economic space can affect the tourism 
development and recreational activities. The most challenging areas for the organization of tourist space are the inland mountainous trans-boundary regions that lie at the periphery of international tourism. These regions include the Himalayas, the Pamirs, the Altai-Sayans and others. Evidently, it is difficult to organize and develop tourist space in such regions because of their remoteness from travel industries and consumers, and low levels of socio-economic development of the regions.

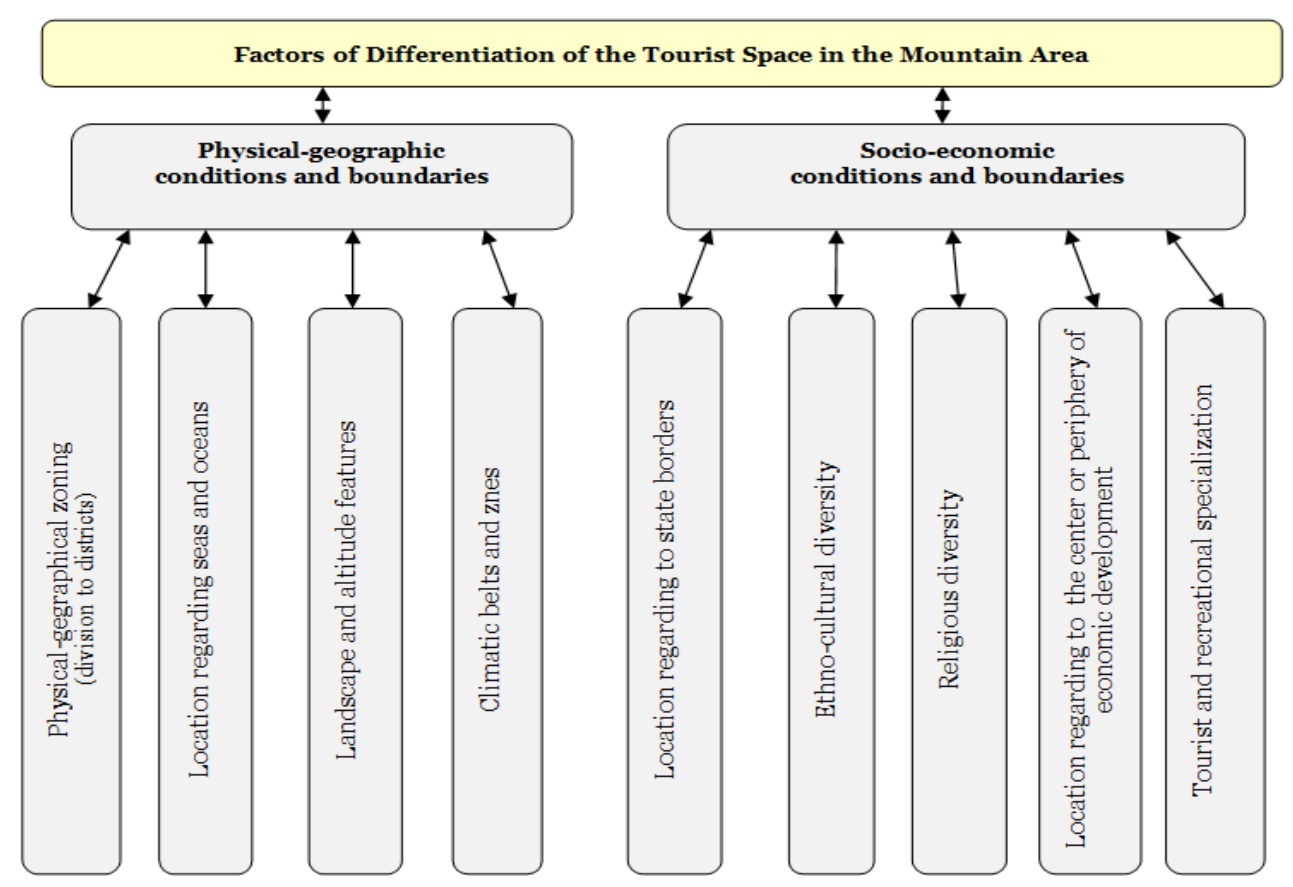

Figure 2. Differentiation of the tourist space of the mountainous region

Over recent decades, the number of tourist activities happening in mountain regions have significantly increased all over world. Furthermore, new technologies and competition among tourism destinations have led to the availability of a wider range of service and activities in the global and regional markets. Governments of many countries and mountain communities consider tourism to be the most essential and integral aspect of their policies in the frame of economic development (Jack et al., 1999). Since tourists can participate in recreational activities in the mountain areas both in winter and summer seasons, the tourist season lasts much longer there than in the lowlands. This yields economic and social benefits for mountain communities (Mironenko \& Bochvarova, 1986).

Our research and analysis of tourism studies (Baburin, 2005; Mironenko \& Bochvarova, 1986; Rudsky, 2000; Suprunenko, 2003) made it possible to identify and describe the following characteristics of mountainous regions that influence the organization of tourist spaces in such regions: tourist activity;

- height and terrain relief roughness, which results in significant diversity of

- a variety of climatic (microclimatic) conditions that determine the vertical and seasonal differences in tourist and recreational activities;

- diversity of landscapes (from steppes or semi desert flat lands to snow-glacial complexes); 
- species diversity, the high concentration of endemic species (plants and animals);

- high degree of environmental sensitivity, vulnerability of natural and culturalhistorical heritage;

- vulnerability of the socio-cultural environment of mountainous regions to all types of external impacts and the urgent need to protect the cultural values of local people and preserve the authenticity of mountain communities.

- increased risks of natural and man-made disasters;

- inaccessible transport system costs associated with economic entities;

- poor economic diversification of mountainous areas related to the traditional economy and lifestyle of mountain people, and the existence of rural settlements there (lower profitability of commercial recreation and tourism enterprises);

- diversity of landscapes providing the development of different tourist activities;

- environmental (natural) barriers (mountain ranges and water bodies), which are one of the most important factors in the formation of state and administrative boundaries;

- trans-boundary location of mountainous regions that results in the interaction of states.

In mountainous regions, tourist space can be characterized by large remote wilderness areas and poor network infrastructure. This is due to high levels of biodiversity, ethno-social groups, and cultural and economic patterns of the regions. It is important to emphasize that the environmental (natural) barriers (mountain ranges and water bodies) are considered to be the most important factors that contribute to the formation of regional boundaries. The development of tourist space and the sustainable development of mountainous areas are closely connected. In addition, tourism studies can play a crucial role both for the development of these regions and the surrounding territories. In addition, tourism studies can play a crucial role both for the development of these regions and the surrounding territories. Furthermore, tourism development in mountainous regions contributes to the improvement of the socio-economic status of the territories. One of the relevant examples is the development of recreational areas in the Alps. It is difficult to imagine this region without its thriving tourism industry. However, it is important to acknowledge that the development of industries (including mining) can damage the environment. Fragile ecosystems continue to be threatened by tourism development. Extreme topography and surface, and inaccessibility of the regions have led to organization of certain types of infrastructure. There are obvious contradictions between the ecological and economic interests of the local people. As a result, land that is considered to be unprofitable for other industries is often relegated to supporting tourism [328]. At present, environmental organizations (UNESCO, WWF and others) contribute to the protection of mountain people's interests and the conservation of biodiversity of the mountain areas. However, commercial recreation and tourism enterprises disregard for environmental standards and requirements have caused conflicts between departments of wildlife protection and representatives of tourism industries.

\section{Characteristics of the Altai-Sayan Region}

The Altai-Sayan region as a model territory is examined at two hierarchical levels: supra-national (natural-historical boundaries) and macroregional (within the borders of the Russian Federation). The tourist-geographical position of the Altai-Sayan Region is remotely located from the main tourist centers. The region is located in the center of the ultracontinental zone. The distance to the sea is $2000 \mathrm{~km}$ and the world's largest urban areas lie far beyond the region. The Altai-Sayan region, located in the center of Eurasia, borders four states. Moreover, it is of strategic importance for the Russian Federation. The Russian region is located in the territories of the Altai, Tyva, Khakassia and partially in the Altai and Krasnoyarsk regions, Kemerovo, Novosibirsk and Irkutsk regions and the south-western part 
Common Characteristics in the Organization of Tourist Space Within Mountainous Regions: Altai-Sayan Region (Russia)

of the Republic of Buryatia. The foreign areas of the region include: eastern regions of the East Kazakhstan region; Altai Administrative District of Xinjiang Uygur Autonomous Region (XUAR, China); twelve aimags (administrative subdivisions) of Mongolia. The AltaiSayan ecoregion is a combination of mountains, coniferous forests, steppe and alpine meadows. Harsh continental climate and complex relief are determining factors for an abundance of flora. The landscape of the Altai-Sayan region is formed by a combination of the middle position within the steppe zone of Eurasia with the predominance of the Asian anticyclone and the leading western transport of Atlantic moisture. There is a contrast and diversity of the altitude-belt zonality of some ridges. The region is characterized by a variety of the orographic features and geographical complexity. There is a shift from boreal forests (taiga) of Siberia to semi-desert and desert landscapes of Central Asia (Figure 3).

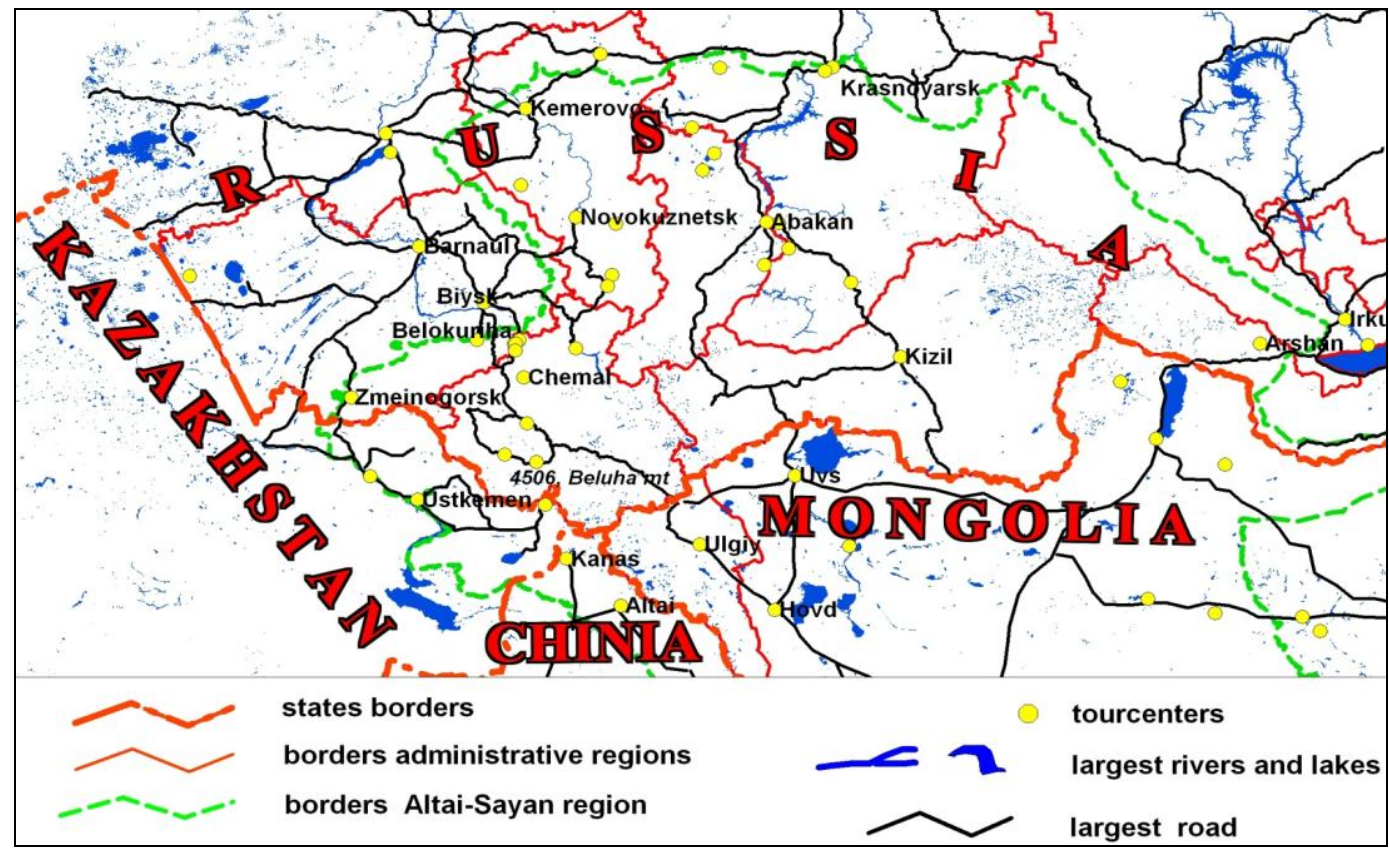

Figure 3. Main tourist centers in the Altai-Sayan region

Furthermore, there have been socio-economic transformations in the neighboring states of the Altai-Sayan region in the late $19^{\text {th }}$ and early $20^{\text {th }}$ century. These changes have contributed to the complexity and the increase of fragmented tourist and recreational spaces: the formation of new administrative entities in the Russian Federation and the emergence of the state - Kazakhstan in the early 1990s, the changing of geopolitical landscape of the region, demographic processes, and a sharp increase in the number of tourist enterprises in some administrative entities. Additionally, changes in legislation defined the concept of ownership (tourist and recreational resources). The period is also characterized by the development of ethno-cultural cooperation between countries (regions), the transformation of the economic structure of administrative entities and the development of trade and economic cooperation. Trans-boundary is related in many ways to geopolitical factors, which are represented at different levels of the organization of tourism. The geopolitical situation for tourism is quite favorable in the region because the political situation is stable. There are no armed conflicts or ethnic tensions. In the region, 
tensions are often caused by: transit-infrastructure policies (road construction and building of economic centers) and eco-regional planning (development of a system of protected areas and improvement of mountainous communities). Modern socio-economic conditions and processes that determine the formation of tourist and recreational space in the administrative entities of the Altai-Sayan region vary significantly. This is due to political-administrative division, national and regional policies and planning. The most productive and economically successful regions are the Kemerovo Region and the Krasnoyarsk Territory, while border territories are not as prosperous. Based on the analysis of tourism infrastructure in the Altai-Sayan region we are able to highlight prominent concerns and propose suitable policies for tourism development.

We have defined the following problems:

- areas are geographically isolated;

- frontier zones make construction of accommodation facilities and organization of tourism more difficult;

- low levels of service;

- disparities in the territorial distribution of the tourism infrastructure;

- tourism flows are determined by transitory and seasonal nature factors;

- inadequate supply of qualified tourism infrastructure/management workers.

Interestingly, the tourist infrastructure is much better developed in the peripheral areas (with the exception of the southern and south-eastern parts of the region, the territory of Mongolia). Important "tourist axes" are being formed, connecting tourist centers. Along the lower course of the Katun River, where many accommodation facilities have been constructed over 100 kilometers from Gorno-Altaisk and beyond the village of Chemal, and along the Chuysky Tract. The most competitive and attractive tourist destinations are tourist centers in Krasnoyarsk, Belokurikha, Kyzyl, Abakan, Novokuznetsk, Sheregesh, the Blue Gulf (Kazakhstan), Khovd (Mongolia), Altai City and Kanas National Park (China). Roads have a great influence on the development of tourism. The main directions of the roads are Novosibirsk, Biysk - Tashanta; Krasnoyarsk-Minusinsk-Kyzyl-Khandagayty; Ulang - Ulgiy - Khovd; Khovd - Altai - Bayarkhohor; Urumqi - Altai - Kanas; Barnaul-RubtsovskUst-Kamenogorsk; Ust-Kamenogorsk - Ridder - Rakhman Keys; Irkutsk - Arshan. There are concerns about the roads connecting the state with the Altai-Sayan region. In recent years, to create favorable conditions for the reception of tourists, construction of roads in Mongolia is underway. It should be noted that efficient transport systems affect tourism development. Major areas of roadways include Novosibirsk, Biysk - Tashanta; KrasnoyarskMinusinsk-Kyzyl-Khandagayty; Ulang - Ulgiy - Khovd; Khovd - Altai - Bayarkhohor; Urumqi - Altai - Kanas; Barnaul-Rubtsovsk-Ust-Kamenogorsk; Ust-Kamenogorsk - Ridder - Rakhman Keys; Irkutsk - Arshan. Several problems impede the development of transport networks, in particular roads connecting the states in the Altai-Sayan region.

In recent years, roadways have been built in Mongolia to improve tourist infrastructure. Building viable roads in the Chinese part of Altai have made it possible to visit Lake Kanas. In addition, international tourism development in the region is associated with the construction of highways. For example, the region's transportation system has failed to meet travelers' needs and has prevented the implementation of the cross-border project known as the "Golden Ring of Altai". Our analysis of the focus and functionality of the tourist centers of the Altai-Sayan region allows us to distinguish specific types: cognitive, recreational, sports - recreational, therapeutic and recreational, multifunctional. Due to the fact that the region is located on the periphery of the economic space, most tourist centers do not have a well-developed infrastructure or significant tourist flows. The emphasis on sustainable development is associated with a growing interest of travelers both 
in lands and communities in acting according to their environmental, cultural and economic values.Due to the geopolitical location, in the center of Eurasia, the Altai-Sayan region united various ethnic groups and cultures. Therefore, in the region there are demands for the formation of an integral tourist-recreational space. The prerequisites include the natural and ethno-cultural similarity of the region, the necessity of cultural and natural heritage of the region, closeness to the markets of neighboring countries, the economic benefits of trade cooperation and the organization of cross-border tourism.

\section{CONCLUSION}

Tourist space in mountainous regions is very unique. On one hand, the diversity of tourism resources can lead to fulfilling the economic potential of the area. However, socioeconomic contradictions have a strong impact on the formation of tourist space. It should also be mentioned that the development of tourism in mountainous trans-boundary regions can foster efficient cooperation among different ethnic groups. In fact, regional studies play an important role in the formation of a methodology that can be applied to study touristrecreational regions. Currently, regional studies qualify as promising scientific directions because they acknowledge that there are distinct types of tourist regions. Mountainous regions can be regarded as separate structures of tourist space at different hierarchical levels. They are characterized by various conditions and factors that determine the formation of tourist complexes. In mountainous regions, landscape differentiation of the territory determines the complexity of socio-economic development of tourist space. Mountainous regions differ significantly. In other words, geographic location, natural and socio-economic conditions, geopolitical status, level of tourist development and specialization of tourist centers influence the development of mountainous regions. The hierarchy of tourist systems and their cross-border status have allowed us to define the levels of tourist regions. Different hierarchical levels of tourist-recreational regions can be correlated with the relevant levels of mountain tourist systems. Mountainous regions of the supranational level are trans-boundary ones. The studies propose that the most effective approach for comparing different mountainous regions is a classification system based on the level of tourism development. This tourist development is characterized primarily by the development of infrastructure. To compare features of the organization of the tourist space in mountainous regions, you can use different indicators. Moreover, it is very important to take into account:

- geographical position regarding to cities and urban agglomerations (a highly developed spatial form of integrated cities.), oceans (coastal, temperate continental and inland);

- natural conditions (climatic belt, annual river runoff in the highlands and on the periphery of the region, high elevation landscape conditions);

- ethno-social conditions (population density, ethnic and religious diversity);

- geopolitical conditions of the region, characterized by relations between the countries of the mountainous region;

- specialization of the main tourist centers (importance of tourist centers for the modern development of tourism in the mountainous region).

Thus, the combination of conditions and factors forms the geographic location of a mountainous region and determines challenges and advantages in the organization of tourist space. The negative points of its formation (tourist space) can be the inland mountainous trans-boundary areas, which belong to the periphery of international tourism. The Altai-Sayan region is one of the inland mountainous trans-boundary areas. Problems with the organization of the inland tourist space include the remoteness from the main tourist centers and low levels of development of the social-economic spheres in the region. 


\section{REFERENCES}

Alexandrova, A. Yu. (2002). Structure of the Tourist Market. Press Solo, Moscow, 195 p.

Alexandrova, A. Yu. (2009). Geography of Tourism. KNORUS, Moscow, 592 p.

Alekseeva, A. I., \& Mironenko, N. S. (2004). Geography, society, environment. Geography of socio-economic development, Gorodets, Moscow, Vol.5, 672 p.

Badenkov, Yu. P. (2002). Trans-boundary mountainous territories under conditions of globalization: Altai Syndrome. Izvestie RAS. Ser. Geogr., (3), pp. 21-28.

Badenkov, Yu. P. (1998). Sustainable Development of Mountainous. Izvestie RAS. Ser. Geogr., (6), pp. 7-21.

Baburin, V. L. (2005). Economic and geographical approaches to mountainous areas management. Sustainable Development of Territories: GIS Theory and Practical Experience: Materials of the International Conference. Publishing House of the SSU, Stavropol, Budapest, pp. 356-358.

Beatty, E. (2008). Alps: from Ljubljana to Lyon and from Munich to Milan. Eksmo, Moscow, Midgrad, 384 p.

Bujdoso, Z., David, L., Varga, D., Zhakupov, A., Gyurko, A., \& Penzes, J. (2015). Tourism development and cross-border cooperation in the Hungarian-Romanian border region. GeoJournal of Tourism and Geosites, 2 (16), pp. 154-164.

Chistyakov, K.V., Kaledin, N.V., \& Moskalenko, I.G. (2010). Mountains and people: changes in landscapes and ethnoses of the inland mountains of Russia. BBM, St. Petersburg, 438 p.

Dunets, A. N. (2009). Territorial organization of mountain tourist-recreational systems (on the example of the Altai-Sayan region). Publishing house of AltSTU, Barnaul, $167 \mathrm{p}$.

Dunets, A. N.(2011). Tourist and recreational complexes of the mountain region. Publishing house of AltSTU, Barnaul, 204p.

Forleo, M. B, Giannelli, A., Giaccio, V., Palmieri, N., \& Mastronardi, L. (2017). Geosites and parks for the sustainable development of inner areas: the Matese Mountain (Italy). GeoJournal of Tourism and Geosites, 22 (20), pp. 231-242.

Godde, P., Price, M., \& Zimmermann, F. (2000). Tourism and Development in Mountain Regions. CABI Publishing, $320 \mathrm{p}$.

Golubchikov, Yu. N. (1996). Geography of the mountainous and polar countries. Publishing house of Moscow University, Moscow, 303 p.

Jack, D. I., Bruno, M., Badenkov, Yu. P., \& Kotlyakov V. M. (1999). Mountains of the world. Global priority. Noosphere, Moscow, 454 p.

Kalesnik, S. V. (1970). General geographic regularities of the Earth. Moscow, 84 p.

Mazhar, L. Yu. (2008). Territorial tourist-recreational systems. Universum, Smolensk, 211 p.

Mironenko, N. S., \& Bochvarova, M. (1986). Recreational systems. Publishing house of Moscow University, Moscow, $136 \mathrm{p}$.

Neidze, V. E. (2007). Problems of modern tourism in mountainous regions of Georgia. Applied questions of geography and geology of mountain areas of the Alpine-Himalayan belt. YSU Publishing House, Yerevan, pp. 467-469.

Price, M. F. (2007). Mountain Area Research and Management: Integrated Approaches. GBR: Earthscan, London, 317 p.

Price, M. F., \& Wachs, E. (1999). Mountains of the world - Tourism and sustainable mountain development. Center for Development and Environment, $48 \mathrm{p}$.

Price, M. F., Jansky, L., Andrei, A., \& Iatsenia, A. A. (2004). Key Issues for Mountain Areas. United Nations University Press, $263 \mathrm{p}$.

Revyakin, V. S., Shvetsov, A. Ya., \& Dunets, A.N. (2001). Anthropogenic Changes in the relief of the Altai-Sayan Mountainous. Geomorphology of Central Asia. Publishing House of Altai State University, Barnaul, pp. 77-79.

Rodoman, B. B. (2002). The Polarized Biosphere. Oikumena, Smolensk, 336 p.

Rudsky, V. V. (2000). Nature use in mountainous countries (on the example of Altai and Sayan). Science, Novosibirsk, $207 \mathrm{p}$.

Samoylova, G. S. (2000). Landscape structure of the Altai-Hanga-Sayan Ecoregion. Mountains and Man: Anthropogenic transformation of mountain geosystems. Publishing house of the SB RAS, Novosibirsk, pp. 111-112.

Seliverstov, Yu. P. (2002). Mountainous territories and their sustainable development (on the concept of the term - montology). RGO, V. 134. (1), pp. 3-10.

Sevastyanov, D. V. (2008). The basics of regional geography and international tourism. Academy, Moscow, p.265.

Sukhova, M. G. (2009). Bioclimatic conditions of human life in the Altai-Sayan mountainous. Publishing house of Tomsk University, Tomsk, $260 \mathrm{p}$.

Suprunenko, Yu. P. (2003). The Mountains are calling ... (Management of Mountain-recreational resources and environment). Tvant, Moscow, 386 p.

Vedenin, Yu. A. (1990). Recreational resources of the USSR (problems of rational use). Science, Moscow, 168 p.

Vijulie, I., Matei, E., Preda, M., Manea, G., Cuculici, R., \& Mareci, A. (2018). Tourism- a viable alternative for the development of rural mountainous communities. Case Study: Eftimie Murgu, Caras-Severin Country, Romania. GeoJournal of Tourism and Geosites, 22 (22), pp. 419-431.

Zhensikbaeva, N., Sarapov, K.,T., Kulzhanova, S.,M., Atasoy, E., \& Wendt, J., A. (2018). Determination of southern Altai geography propitiosness extent for tourism development. GeoJournal of Tourism and Geosites, 22 (20), pp. 158-164.

*** Resources and environment: Wold Atlas. (1998). Austria, Vienna.

Submitted:

28.11.2018
Revised:

11.02.2019
Accepted and published online 14.02.2019 